\title{
OPIATE OF THE MASSES? INEQUALITY, RELIGION, AND POLITICAL IDEOLOGY IN THE UNITED STATES
}

\author{
Landon Schnabel ${ }^{*}$ \\ Stanford University
}

\begin{abstract}
:
This study considers the assertion that religion is the opiate of the masses. Using a special module of the General Social Survey, I first demonstrate that religion functions as a compensatory resource for structurally-disadvantaged groups — women, racial minorities, those with lower incomes, and, to a lesser extent, sexual minorities. I then demonstrate that religionoperating as both compensatory resource and values-shaping schema-suppresses what would otherwise be larger group differences in political ideology. This study provides empirical support for the general "opiate" claim that religion is the "sigh of the oppressed creature" and suppressor of emancipatory political values. I expand and refine the theory, however, showing how religion provides (1) compensatory resources for lack of social, and not just economic, status, and (2) traditional-values-oriented schemas that, rather than just distracting people, shape their politics in accordance with the content of religious belief systems.
\end{abstract}

Key Words: Inequality; Religion; Politics; Values; Gender; Race and Ethnicity; Class; Sexuality; Culture; Social Psychology

Last Revised: $\mathbf{2 / 2 4 / 2 0 2 0}$

Running Head: Opiate of the Masses?

Figures: 1

Tables: 6

Forthcoming in Social Forces

\footnotetext{
* The author is grateful to Brian Powell for exceptional feedback. He would also like to thank Art Alderson, Chris Bader, Clem Brooks, Youngjoo Cha, Andreas Ferrara, Andy Halpern-Manners, Patricia McManus, Chris Munn, Roshan Pandian, Brian Steensland, Allison Schnable, Evan Stewart, Jenny Trinitapoli, Robb Willer, the anonymous reviewers, the Indiana University Politics, Economy, and Culture Workshop, the Indiana University Social Psychology, Health, and the Life Course Workshop, and the Stanford Politics, Morality, and Hierarchy Workshop for helpful input. This project was presented and benefited from comments at the 2017 meetings of the American Sociological Association, Association for the Sociology of Religion, and Society for the Scientific Study of Religion, as well as the 2018 Younger Scholars in the Sociology of Religion Workshop and the 2018 Institute for the Study of Economics, Religion, and Society Student Workshop. Direct correspondence to Landon Schnabel, Department of Sociology, Stanford University, 120, 450 Jane Stanford Way \#160, Stanford, CA 94305. Email: landons@stanford.edu.
} 
Religious suffering is, at one and the same time, the expression of real suffering and a protest against real suffering. Religion is the sigh of the oppressed creature, the heart of a heartless world, and the soul of soulless conditions. It is the opium of the people.

-Karl Marx (1970 [1843])

Whenever a candidate or policy that advantages the few while disadvantaging the many wins an election, pundits assume people voted against their own self-interests and then wonder why. For example, after the 2016 U.S. presidential election many wondered why women did not vote more consistently for the first woman nominated by a major party. Status and positionality theories of politics excel at predicting why structurally-disadvantaged groups often support and vote for progressive candidates and policies, but these theories break down in the not infrequent cases when disadvantaged groups are not liberal. For example, as I will show, men are more supportive of a woman's right to choose abortion than are women. Are disadvantaged groups simply irrational, or is there a missing piece or overlapping identity that, when added to positionality theories of politics, explains otherwise unexpected attitudes and voting behavior?

Marx, Du Bois, Weber, and other classical social theorists said religion appeals to the disenfranchised and helps them through suffering. But, according to these theorists, negatives accompany the positives, with religion legitimating subordination and/or distracting people from the root causes of their suffering. Marx's version of the "opiate" argument would predict that religion constrains revolution by suppressing political engagement. Yet, in the contemporary United States and many other countries, the most intensely religious people are often the most politically engaged, having an outsized impact on politics (Bolzendahl, Schnabel, and Sagi 2019). Although religion does not seem to make people apolitical, it is still possible that religion legitimates the status quo. Applying and synthesizing several theoretical traditions-including structuration (Giddens 1984; Sewell 1992), system justification (Jost and Hunyady 2002), compensatory control (Kay et al. 2009), and related cultural and social psychological approaches 
to the study of religion (Edgell 2012; Hoffmann and Bartkowski 2008)—I explore, expand upon, and refine the classic "opiate" argument.

In the process of exploring the "opiate" argument, this study answers, at least in part, two broader social scientific questions: (1) Why are some groups consistently more religious than others? (2) Why do attitudes toward certain social issues, such as abortion and same-sex relationships, seem to contradict the positionality principle of disadvantage promoting progressive values? I conclude that, as Marx and others have argued, religion can legitimate inequality. But I propose a new mechanism: Rather than suggesting that religions make people less political, less agentic, or more irrational, I argue that religions shape political ideology in accordance with the deeply-held identities, interests, and values of agentic people with multiple overlapping identities seeking meaning and wellbeing in the face of uncertainty and injustice. By acting as a compensatory resource that disproportionately provides comfort and strength to the disadvantaged and a schema that disproportionately shapes their political ideology according to traditional religious values, contemporary American religion — and Christianity in particularsuppresses what would otherwise be larger group differences in political ideology.

\section{AN ATTEMPT TO OPERATIONALIZE CLASSICAL SOCIAL THEORY}

Although the "opiate" argument is frequently invoked theoretically, the mechanism by which religion is said to operate as an opiate remains underspecified and undertested. Three primary propositions can be extracted from the argument: 1) religion appeals and provides comfort to the disenfranchised, which 2) makes them more religious, which 3) affects their politics. In the process of operationalizing the "opiate" function of religion we need to first measure the greater comfort religion is said to provide to the disenfranchised. I propose and use compensatory psychological benefits from religion-including comfort received from religion and 
spirituality—as a way to measure and examine the potential opiate function of religion. The idea that religion and spirituality provide comfort, consolation, and validation is central to some theoretical frameworks (e.g., deprivation-compensation hypothesis), but these compensatory factors often go unmeasured in nationally-representative research (see Pargament, Feuille, and Burdzy 2011 on measurement in convenience samples).

In the view of Marx and others, including Davis (1971) who applied the argument to the American experience, religion provides comfort to the disadvantaged which then makes them more religious and thereby suppresses their political consciousness. Status and identity theories like the "underdog principle" suggest disadvantaged groups develop progressive identity and partisanship because they face marginalization, recognize structural inequalities, and have sympathy for and solidarity with other disadvantaged groups (Davis and Robinson 1991; Hunt 2007). Yet, structurally-disadvantaged groups are not always more progressive on particular issues, especially those closely linked to religious values-for example, abortion, same-sex marriage, and physician-assisted suicide (Schnabel 2018b). Quiescence—or the absence of collective activism against deprivation and injustice (Gaventa 1982)—lack of group-based consciousness and solidarity, and what appear to be self-defeating political attitudes among structurally-disadvantaged groups (Jost et al. 2017) are foundational puzzles across the social sciences. A few studies suggest religion can suppress progressivism on individual issues among women and racial minorities (Adamczyk, Boyd, and Hayes 2016; Barkan 2014; Sherkat, DeVries, and Creek 2010; Wilcox 1992), but religion may operate as a more general suppressor of progressive politics.

This study first considers whether groups with less power and status-women, Black and Latinx Americans, those with lower incomes, and sexual minorities - receive more psychological 
compensation from religion and spirituality. It then examines whether psychological compensation is implicated in sociodemographic differences in religiosity. After considering the extent to which religion operates as a compensatory resource, I consider the extent to which religion operates as a traditional-values-oriented schema implicated in sociopolitical attitudes. In the course of testing hypotheses related to the opiate-of-the-masses thesis, I find empirical support for the general claim that religion is the "sigh of the oppressed creature," "heart of a heartless world," and suppressor of emancipatory political values. I expand and refine the theory, however, showing how religion provides (1) compensatory resources for lack of social, and not just economic, status, and (2) traditional-values-oriented schemas that, rather than just distracting people, shape their politics in accordance with the content of religious belief systems.

\section{RELIGION AS RESOURCE}

\section{Deprivation and Religious Compensation}

Deprivation-compensation theories have long been used to explain religion's widespread appeal in the human experience. K. Davis (1948) contended that the greater a person's disappointment and frustration in this life, the more they would focus on a future life. According to Davis, focusing on goals beyond this world allows people to compensate for frustrations trying to reach present goals. Stepping back from more individual hardships, we might think about the broader human experience and the possibility that humans want at least the hope of a utopia. That utopia could be in the here-and-now, or it could be in the by-and-by. And the more people think they will get the one, the less they need the other. Conversely, the less hope they have in one, the more they need the other. In other words, the further from utopia their current experience is the more people shift their focus to a better future life as Stark and Bainbridge (1987) highlighted when they said religion provides "supernatural general compensators" that replace unavailable 
material rewards with future spiritual rewards. Therefore, as far as the human experience leads to unmet material needs, people will seek future immaterial compensation. Benefits provided by religion were foundational in the rational-choice framework for religion (Stark, Iannaccone, and Finke 1996), and what people do with and get from religion in their everyday lives (e.g., receive comfort and make meaning out of hardship) has become all the more salient in light of the more recent cultural turn in the sociology of religion drawing on concepts such as structuration (Edgell 2012; Hoffmann and Bartkowski 2008).

Structuration theory argues that social structures like religion are composed of both resources and schemas. Resources are cultural objects or products that help people reach objectives or enhance status, power, and wellbeing, whereas schemas are sets of rules or norms for social beliefs and actions (Giddens 1984; Sewell 1992). Resources and schemas are interrelated structural components that mutually reinforce one another — so that, for example, certain types of religious beliefs (schemas) could provide more compensatory benefits (resources), and compensatory benefits from religion could promote greater commitment and adherence to religious schemas (Hoffmann and Bartkowski 2008). Someone facing hardship in their everyday life could find comfort in a compensatory belief system that transcends their current hardship and/or lack of power, the comfort they receive could be expected to make them more committed to that belief system, and further commitment to and involvement in that belief system could provide them even more social psychological benefits in a mutually-reinforcing loop. Likewise, intersectionality and identity theories argue that people have multiple competing identities tied to interrelated social structures — such as gender, race, class, sexuality, and religion - and lack of status and power in one area can increase the salience of other identities. 
For example, a woman may find validation and support in religion that compensates for lack of status in regard to gender (Schnabel 2016b).

Marx focused on class and material deprivation, and the rare empirical tests of his "opiate" concept focus on whether better material conditions reduce religiosity (Becker and Woessmann 2013; Wimberley 1984). In what may be the clearest example of an explicit empirical test of Marx’s argument, Becker and Woessmann (2013) used historical data to determine if improvement in material conditions produced secularization. Because county-level salary increases did not yield secularization, they concluded religion is not the opiate of the masses. ${ }^{1}$ The "opiate" argument deserves further empirical examination that, in addition to considering the relationship between income and religiosity, considers psychological compensation and its impact on politics.

Marx’s argument could logically extend beyond economic inequality to social inequality in contemporary American society. Certainly, economic standing remains a key social divide, but gender, race, and sexuality are also central to contemporary American religious life (Edgell 2017; Edgell and Docka 2007). Accordingly, scholars argue that social divides and forms of deprivation besides material hardship, such as lack of status and power, could also motivate religiosity (Christopher et al. 1971; Ellison and Taylor 1996; Glock 1964). Du Bois (1903), for example, made statements about race and religion complementary with those of Marx about class and religion, and A. Davis (1971) noted how Marx's argument could be applied to class, race, and gender. The deprivation-compensation hypothesis remains central to theories about religiousness, but is more often used as a post hoc explanation for group differences in religiosity than explicitly measured.

\footnotetext{
${ }^{1}$ Other research shows societal economic hardship (Storm 2017) and disasters (Bentzen 2018) promote religiosity.
} 


\section{Social Status and Group Differences in Religiosity}

A large and contentious literature focuses on why women are more religious than men in Christian contexts. Gender differences in religiosity are typically considered in isolation, but could be considered in the context of other group differences. With the exception of sexual minorities who have been further marginalized by religious institutions (Sherkat 2016; Wedow et al. 2017), disadvantaged groups are typically more religious and more religiously orthodox than their more advantaged counterparts in Christian contexts. This pattern may be due, at least in part, to religion and spirituality providing compensatory comfort, strength, control, and validation (Hoffmann and Bartkowski 2008; Schnabel 2016b, 2018a).

Some research emphasizes the material deprivation and insecurities women face (Norris and Inglehart 2011), but other research argues that lack of social status and power may be more important for understanding why women are often more religious than men (Hoffmann and Bartkowski 2008; Schnabel 2016b). This literature also suggests the American religious context, where Christianity predominates, promotes gender and other social status differences in religiosity because Christianity is perceived as a sympathetic underdog religion that, as noted by Marx and later feminist Marxists such as Davis (1971), appeals to the disadvantaged. Although past research has argued that Christian religion provides comfort, strength, and support to the disadvantaged, these potential compensatory benefits to everyday lived religion often go unmeasured in nationally-representative research.

The literature on racial gaps in religiosity similarly emphasizes the importance of social status, but also highlights potentially distinctive processes when religion is both comprised of and run by a structurally-disadvantaged group. Ellison and Sherkat (1995) highlight how religion holds a distinctive place in the Black community, arguing that it can operate as a "semiinvoluntary institution" among African Americans. The centrality of the Black church developed 
through a history of oppression and marginalization that made church a refuge, community center, and beacon of hope in a racist world, providing compensation for lack of status in the world outside the church (Du Bois 1903). Therefore, we might similarly expect that social psychological benefits to religion would help explain why Black Americans are particularly religious. Though, at the same time, community expectations and institutional structures among African Americans over-and-above the more individual benefits to religion suggest racial differences in religiosity may be larger - and less fully explained by psychological compensation - than other group differences.

The first step toward a more comprehensive examination of inequality and religion is to test whether structurally-disadvantaged groups receive more compensatory benefits from religion. And the next step is to examine the extent to which group differences in religiosity are a function of psychological compensation. I expect that disadvantaged groups receive more compensatory benefits from religion than more advantaged groups, and that these benefits help explain group differences in religiosity.

Expectation 1: Disadvantaged groups —including women, Black and Latinx Americans, those with lower incomes, and sexual minorities-receive more compensatory psychological benefits from religion and spirituality than their more advantaged counterparts.

Expectation 2: Sociodemographic differences in religiosity are in part a function of psychological compensation.

The relationship between psychological compensation and religiosity is likely reciprocal. We might expect marginalized groups to be drawn to religion because of what it provides, and the more religious they are the more they get from it. A self-reinforcing feedback loop is consistent with "opiate" and resource frameworks, but if marginalized groups simply receive more psychological compensation from religion because they are more religious it would point 
to different underlying mechanisms. Therefore, I will also consider the inverse relationship, testing whether group differences in compensation are simply a function of religiosity.

Alternative to Expectation 2: Sociodemographic differences in psychological compensation are primarily a function of religiosity.

\section{RELIGION AS SCHEMA}

\section{Religion and Apparent Inconsistencies in the Positionality Principle}

According to positionality and status theories of political values (Davis and Robinson 1991;

Hunt 1996, 2007), group position and awareness of structural reasons for inequality make disadvantaged groups less likely to believe in legitimating ideologies of racism, sexism, nationalism, etc. that justify social hierarchies and inequalities (Frost and Edgell 2017; Sidanius, Pratto, and Bobo 1994), more likely to recognize and distrust oppressive norms, policies, and institutions (Collins 2000), and, therefore, more likely to develop progressive politics across a broad range of issues (Davenport 2016). This "underdog" positionality principle is generally compatible with Marx's notion of group-based emancipatory politics, but differs in its focus on social status instead of economic status and is typically applied to gender, race and, more recently, sexuality.

The status, positionality, and politics literature shows that women and racial minorities are more progressive on issues related not just to their own wellbeing, but across other issues as well (e.g., women tend to hold less racist attitudes than men). A recent study applied the positionality principle to sexual minorities — who tend to be less religious and practice more inclusive forms of religion due to their marginalization by many religious groups - and found they're consistently more liberal than heterosexuals (Schnabel 2018b). In that study, women and Black Americans were more liberal on many topics, but on social issues tied to traditional 
religious teachings — such as abortion, sexuality, and suicide - they were just as if not more conservative than their more advantaged counterparts.

Scholars working from status-based frameworks for public opinion and politics frequently neglect religion as a potential explanation for unexpected null or even reverse findings. In popular usage, the phrase "opiate of the masses" is often employed to refer just to consolation and happiness premiums provided by religion. But Marx argued that people seek comfort in religion and that religion suppresses emancipatory politics, thereby preventing the masses from revolting against those in power. According to Marx (1970), religion is an "inverted consciousness" that responds to disadvantageous material conditions with nonmaterial compensators. This compensatory spiritual focus of Christian religion is said to then limit the development of emancipatory values to address the disadvantageous conditions that made religion and spirituality more appealing (also see Du Bois 1903; Davis 1971). ${ }^{2}$

Complementing Marx’s argument—and consistent with theories of system justification, compensatory control, and social dominance (Jost et al. 2014; Kay et al. 2010)—Simmel posited that subordinated groups are more likely to accept social domination, and less likely to develop status-based politics, if those above them in the social hierarchy are perceived as spiritually subordinate to a caring, personal, and just higher authority in which the subordinated find support and a sense of fairness. ${ }^{3}$ A. Davis (1971) said "religion can play both a positive and a negative role in that road toward self-knowledge. It can thwart liberation-and this [was] the

\footnotetext{
${ }^{2}$ Marx (1970) argued that to struggle against religion is to struggle against unequal conditions that make religion appealing. Davis (1971) "concur[red] with Marx that one must overcome religion in order to regain one's reason" and said that "effective protest against oppression must be articulated and acted upon in a political [i.e., not spiritual] context." But Davis also noted that "the illusory nature of religion may well be transcended within the limits of religion," using Nat Turner to illustrate how religion can be repurposed for emancipation. Similarly, Du Bois (1903) said religion both limits consciousness and provides a social center that could be leveraged for social change. Despite being system-justifying on average, religion has emancipative potential.

${ }^{3}$ Weber similarly argued other-worldly religion can alleviate this-worldly suffering and Durkheim that religion legitimates social arrangements.
} 
express purpose for converting the slave_or it can provide powerful assistance" (p. 17). In her words, religion serves a positive purpose as "a much needed medicine which helps to allay suffering" (p. 16), but is, at the same time, a suppressor of emancipatory politics when it projects "real needs and desires into a supernatural domain" and provides a way of thinking that justifies rather than challenges systemic inequality (p. 17; also see Jost et al. 2014).

Similar to Marx, structuration and compensatory control theories predict that religion both provides comfort and influences politics. But whereas Marx focused on palliative distraction, applying structuration and compensatory control theories to religion would suggest it provides a compensatory resource and a cultural schema, or set of cultural rules, for thinking about, motivating, and justifying moral values and behavior (Hoffmann and Bartkowski 2008; Vaisey 2009). In other words, religion provides a cultural toolkit that people draw upon to make sense of their everyday lives, thereby actively shaping their social values and actions rather than just distracting them (Jost et al. 2014; Swidler 1986).

Recent cultural and social psychological approaches to the study of religion confirm religion is a potent resource with substantial symbolic power. People use religion to make meaning out of their everyday lives (religion as resource), and religion as a legitimating force can then promote exclusionary symbolic boundaries (Edgell 2012) and motivate or constrain social action (Vaisey 2009; Willer 2009) in ways that justify and exacerbate systemic inequalities (Jost et al. 2014) (religion as schema). More specifically, religion promotes systemjustifying beliefs that enforce exclusionary moral boundaries and highlight individual responsibility over systemic causes of inequality (Haidt 2012; Jost et al. 2014).

When religion is used as a comfort-providing and meaning-making cultural tool, its symbolic power could facilitate moralistic rather than emancipatory belief systems, legitimate 
power structures, and promote inequalities (Edgell 2012; Haidt 2012). Some small countercultural religious groups explicitly promote progressive values (e.g., Unitarian Universalists and Quakers) and larger traditions run by marginalized groups have at times mobilized for certain progressive issues (e.g., racial equality in the Civil Rights Movement). But, on average, the predominantly-Christian religious schemas in the United States tend to be rooted in teachings established at a particular point in time, and are often centered on traditional norms that harken to the past or even "eternal truths" antithetical to social change. Even "liberal" religion often ends up suppressing radical views on social change, frequently promoting respectability politics and selective conservatism on certain social issues (e.g., sexuality). In fact, the term "politics of respectability" was coined to describe women in the Black church seeking to advance the status of African Americans by pushing individual responsibility and admonishing them to be temperate, tidy, polite, and morally pure rather than seeking radical systemic change (Higginbotham 1993).

Symbolic boundaries in the current American religious landscape are demarcated by values related to gender, sexuality, and other issues closely related to specific religious teachings and norms (Edgell 2012; Schnabel 2016a). And in American religion, belief systems (e.g., biblical literalism) and groups (e.g., fundamentalists) that emphasize an interventionist God demonstrate especially large status differences in adherence and particularly conservative system-justifying schemas (Hoffmann and Bartkowski 2008). Supporting the possibility that American religion is, on average, an actively socio-politically conservatizing force, it is primarily issues linked to religion on which disadvantaged groups are sometimes more conservative than their counterparts (Adamczyk et al. 2016; Barkan 2014; Schnabel 2018b). 
Although religion as a suppressor of progressive values has not been broadly examined, cultural and social psychological approaches highlight the identity- and outlook-shaping power of religion (Edgell 2012; Jost et al. 2014; Kay et al. 2010) and a few studies have suggested religion suppresses progressivism on one or two specific issues (Barkan 2014; Wilcox 1992). Although not framed as a test of the "opiate" concept, these studies provide some indication that religion could help account for why we don't always find the group differences in politics we might expect based on the positionality principle.

Moving from the theoretical to the empirical and directly testable, a suppressor variable is a measure that conceals the strength of a relationship, such as the relationship between disadvantaged social status and progressive political views. This occurs when a variable is associated with two other variables in opposite directions. If, for example, disadvantaged groups receive more comfort from religion and comfort from religion is associated with sociopolitical conservativism, then this comfort, as Marx proposed, suppresses what would otherwise be larger and more consistent positionality-based group differences in politics.

Based on Marx's argument about religion-as-distraction, comfort from religion (i.e., religion-as-resource) would directly suppress group differences in politics. But structuration theory would suggest that religion as structure is both resource and schema. Whereas we could expect religion-as-resource to explain why disadvantaged groups are more religious, we might expect religion-as-schema to be the reason religion shapes politics. This process is illustrated in Figure 1: social disadvantage leads to using religion as a resource, using religion as a resource promotes internalization of religious schemas, and religious schemas shape political ideology. ${ }^{4}$

\footnotetext{
${ }^{4}$ I present some relationships as reciprocal, using larger arrows for the direction with more established theoretical support and smaller arrows for the reverse directions for which there is also theoretical basis. I'll typically model the relationships according to the pathway of the larger arrows, though at times I'll also consider the reverse. Estimates
} 
Based on structuration and system justification theories, I expect that religion-as-resource will suppress progressive political views among disadvantaged groups via religion-as-schema.

Expectation 3: Religious compensation (resource) suppresses progressive political views among disadvantaged groups via religiosity, literalism, and fundamentalism (schema).

[Figure-1]

\section{Social Values, Economic Values, and Partisanship}

There are a few possible mechanisms by which religion could operate as an "opiate." These cannot be fully tested with the available data, but we can explore which are most consistent with the data. One possibility is that religion simply distracts and diverts people, making them less political. That may be the case with some small religious groups that eschew society and/or politics (e.g., Amish and Jehovah's Witnesses), but we know that religious people as a whole are just as if not more politically engaged than their less religious counterparts. Given that American religion is not making people less political, how might it still act as an opiate?

Marx would suggest that religion should be particularly important for economic politics, but structuration theory would argue that religion should be particularly important for whatever rules-based moral schemas religions promote among their adherents. Religion and conservative politics are closely linked in the contemporary United States with its politicized religiosity (Hout and Fischer 2014; Putnam and Campbell 2010), and religious schemas more closely linked to moralistic social values, especially on issues such as gender and sexuality, than economic values (Finke and Adamczyk 2008; Hitlin and Vaisey 2013; Schnabel 2016a).

I expect that religion is particularly potent in shaping views on specific issues tied to religious moral teachings. Because of their greater connection and commitment to religious

from models with unidirectional assumptions will, of necessity, have some imprecision insofar as they are reciprocal rather than purely unidirectional relationships. 
communities and their teachings, religion could have an outsized impact on the social attitudes of marginalized groups, especially on particular issues where (largely Christian) American religions often have specific and conservative teachings (e.g., abortion, same-sex marriage, suicide, etc.). Put simply, people from marginalized groups may be internalizing and seeking consistency with the teachings and norms of their religious communities. This possibility highlights the complex negotiation of multiple overlapping identities: i.e., religious identity salience shapes people's politics in ways that we might not expect on the basis of gender, race, or class alone.

Expectation 4: Religion is a particularly strong suppressor of specific social/moral issues, such as abortion, salient in religious schemas.

Two alternatives are worth considering. First, perhaps religion simply acts, as Marx suggested, as an inverted consciousness that takes people's concerns away from material things that directly affect them, thereby making them less opposed to material inequality. The second possibility is more likely in the contemporary American context in which religion is entangled with political partisanship. Perhaps religion simply suppresses partisan sorting so that marginalized and highly religious people are less likely to identify with the ideological stance or political party that seems to work on their behalf, and this partisan sorting — rather than impartation of religious schemasexplains away any suppression of group differences on specific social issues.

First Alternative to Expectation 4: Religion is just as if not more potent in suppressing group differences on economic issues than social issues.

Second Alternative to Expectation 4: Partisanship explains away any suppression on specific social issues.

\section{METHODS}

\section{Data and Measures}

The U.S. General Social Survey is a repeated nationally-representative survey. I first use data from a 2004 special module that includes measures of religious psychological compensation. I 
then examine more recent data from 2008 to 2018 that provide a larger sample size for more measures, and a better measure of sexual orientation.

\section{Gender, Race, Class, and Sexuality}

Gender is measured as woman=1 and race/ethnicity as four categories (non-Latinx-white, nonLatinx-Black, Latinx, and non-Latinx-other-race). Class is measured by whether inflationadjusted family income was above or below $\$ 100 \mathrm{k}$ (approximately the $90 \%$ vs. the $10 \%$ additional analyses with other measures yield similar results). ${ }^{5}$ In analyses including data before 2008, sexuality is measured with behavior (same-sex partners in last five years, opposite-sex partners only, or no partnering information). Analyses with data from 2008 forward use the new self-identified orientation measure (lesbian/gay/bisexual vs. heterosexual). ${ }^{6}$ Table 1 presents descriptive statistics.

\section{[Table-1]}

\section{Psychological Compensation}

Psychological compensation is measured with seven questions from a broader scale of everyday experiences with religion and spirituality ("Daily Spiritual Experience Scale") fielded as part of a GSS special module in 2004. Although the Daily Spiritual Experience Scale is correlated with other religion measures, it is distinct from and important for psychological well-being aboveand-beyond them (Ellison and Fan 2008). The items asked how frequently (never or almost never $=1$ to many times a day=6) people have the following experiences:

\footnotetext{
${ }^{5}$ The $99 \%$ vs. $1 \%$ would be closer to Marx's argument—or, better yet, a measure of wealth—but the sample isn't large enough for such comparisons. Additional analyses considered alternative measures - continuous income, class identification (not asked of everyone), and subjective economic status (not asked of everyone) - and found similar patterns. Subjective economic status was a particularly strong predictor of psychological compensation, indicating that social status may be more important than actual material resources for the patterns in this study. I control for education to better isolate economic circumstances from educational experiences.

${ }^{6}$ When data are missing on self-identified sexual orientation but available for sexual partnering, I use last-fiveyears-partnering to classify sexual orientation.
} 
1. I find comfort in my religion or spirituality.

2. I find strength in my religion or spirituality.

3. During worship, or at other times when connecting with God, ${ }^{7}$ I feel joy which lifts me out of my daily concerns.

4. I ask for God's help in the midst of daily activities.

5. I feel guided by God in the midst of daily activities.

6. I feel God's love for me, directly.

7. I feel God's love for me, through others.

Factor analysis yielded a one-factor solution. I conducted all analyses first with this onefactor solution and then a summative scale $(a=.96)$ and found the same patterns, and therefore present results for the summative scale. This psychological compensation scale is empirically distinct from my other religion measures, with the highest correlation - .62 with religiosityfalling below .7. Although psychological compensation is distinct from the other religion measures, it is clearly interrelated with them, and these relationships are likely reciprocal. When considering whether psychological compensation helps account for group differences in religiosity I will present results going in both directions to consider whether psychological compensation does more to explain group differences in religiosity, or whether group differences in religiosity does more to explain group differences in psychological compensation.

\section{Religiosity, Literalism, and Fundamentalism}

In analyses using the 2004 special-module compensation items, religiosity is measured with two key commitment and practice measures: (1) strength of religious affiliation (no affiliation=1 to strong affiliation=4) and (2) attendance frequency (never=1 to more-than-once-a-week=9). Analyses using more recent 2008-2016 data also include a newer measure of religious salience

\footnotetext{
${ }^{7}$ The following preceded these items: “A number of items use the word 'God.' If this word is not a comfortable one, please substitute another idea that calls to mind the divine or holy for you."
} 
(not religious $=1$ to very religious $=4$ ), as well as a measure of prayer frequency (never $=1$ to several-times-a-day=6). ${ }^{8}$

Not all religious schemas are the same, and we might expect certain schemas to be more socio-politically conservatizing than others (e.g., fundamentalist vs. liberal religious traditions). Structurally-disadvantaged groups may be both more religious and more likely to adhere to schemas rooted in an interventionist divine order, including biblical literalism and fundamentalism (Hoffmann and Bartkowski 2008; Young, Willer, and Keltner 2013). I measure literalism with a three-category item: Bible is (1) a book of fables, (2) inspired but not literal, or (3) literal word of God. I measure type of affiliation with the GSS-formulated fundamentalism measure, which categorizes affiliations into three groups with distinct schemas relevant to politics: (1) liberal, (2) moderate, and (3) fundamentalist (Smith 1990, 2018). I use this affiliation measure because it classifies by group-level religious schemas. As will be noted, additional analyses consider other categorization approaches (including RELTRAD, which complicates considerations of race due to its "Black Protestant" category).

\section{Political Views}

This study considers several measures of political attitudes, identities, and behaviors, including general measures of political partisanship, party affiliation, and self-reported voting. I also include attitudes about specific social issues on which some marginalized groups are not consistently more progressive selected based on previous research (Schnabel 2018b). I will present detailed results for an abortion scale and summarize patterns for a number of additional items including views on same-sex relationships, legislation of morality, physician-assisted

\footnotetext{
${ }^{8}$ I first considered each religiosity measure individually, finding similar patterns across measures. I then conducted latent factor analyses; the measures fit together well, loading on one factor. One-factor solutions and standardized summative scales provide the same patterns. I excluded prayer from the religiosity scale in the 2004 analyses due to possible conceptual similarity and higher correlation with the psychological compensation scale.
} 
suicide, and corporal punishment. To consider economic attitudes, I will present detailed results on support for redistribution and summarize patterns for additional items including views on organized labor, the right to an adequate standard of living, and causes and consequences of economic inequality.

\section{Additional Covariates}

The models also include sociodemographic covariates: age (in years), education (categorical measure of highest degree attained), marital status (married=1), parental status (parent=1), region (South=1), rurality (rural=1), and dummies for survey year.

\section{Analytic Strategy}

The study uses all observations with data on psychological compensation and on religiosity, each of which are dependent variables in different models. Sample sizes for other analyses vary by availability of outcome measures. Missing data on independent variables are imputed using chained equations. ${ }^{9}$ OLS regression is used for continuous outcomes and Sobel-Goodman mediation tests determine percentage and significance of total-effect-of-an-independent-variableexplained by mediator variables. This method first regresses dependent variable on independent variable, then mediator/suppressor variable on independent variable, and then dependent variable on both the independent variable and mediator/suppressor variable. These models account for covariates. Sobel-Goodman tests were conducted using a Stata user-written program (sgmediation) and cross-checked with the KHB method (using the khb user-written program). ${ }^{10}$

\footnotetext{
${ }^{9}$ Race, gender, marital status, region, and rurality had no missing data, and those missing income, sexuality, literalism, or fundamentalist data were included as separate missing categories (see Table 1). Data imputed for $<1 \%$ of the sample on parental status, age, and education. Regression analyses use multiply-imputed data (20 imputations). Mediation analyses use single imputation for compatibility with the sgmediation Stata user-written program.

${ }^{10}$ Additional analyses with bootstrapped standard errors didn't alter the results.
} 
Outcomes are standardized (mean=0, $s d=1$ ), which means that coefficients presented in the tables represent group differences in standard deviations.

I first examine whether disadvantaged groups score higher on psychological compensation. I then consider the extent to which group differences in religiosity are a function of this compensation. Finally, I explore the argument that religion suppresses group differences in progressive political views, considering (1) general political identities, attitudes, and behaviors, (2) social attitudes, and (3) economic attitudes.

\section{RESULTS}

\section{Religion as Resource}

Let's first consider group differences in religious psychological compensation in the context of group differences in religiosity, literalism, and type of affiliation. The first model in Table 2

presents compensatory psychological benefits by gender, race/ethnicity, class, and sexuality. Women, Black and Latinx Americans, those with lower incomes, and sexual minorities each receive more compensatory benefits from religion than their counterparts. Women score .44 of a standard deviation higher on psychological compensation than men, and Black .60 and Latinx Americans .40 of a standard deviation higher than non-Latinx whites. Those with incomes under $\$ 100 \mathrm{k}$ score .28 of a standard deviation higher on compensation than those with higher incomes, and sexual minorities score .41 of a standard deviation higher than heterosexuals.

[Table-2]

Table 2 also presents group differences on a religiosity scale, as well as ordered measures of view of the Bible (literalism is the highest category) and type of affiliation (fundamentalism is the highest category). Like the psychological compensation scale, these measures are standardized. Disadvantaged groups are generally more religious, have a higher view of the 
Bible, and are more fundamentalist. Sexual minorities — frequently marginalized by organized religion, especially in fundamentalist contexts and via certain literalist interpretations - score significantly lower on religiosity, literalism, and fundamentalism despite scoring higher on psychological compensation. Disadvantaged groups tend to score higher across the measures presented in Table 2, but group differences tend to be largest on psychological compensation. ${ }^{11}$

Overall, the patterns are consistent with Marx's claim that religion provides psychological compensation, but this extends beyond Marx's focus on those with less material status to those with less social status. The similar patterns across gender, race, ethnicity, class, and sexuality clearly confirm Expectation 1: groups with less social status receive more compensatory benefits from religion and spirituality.

Religion provides psychological benefits to the disadvantaged, but do these benefits help account for sociodemographic differences in religiosity? Table 3 presents group differences in religiosity before and after accounting for compensation. ${ }^{12}$ When accounting for psychological compensation, women are no longer more religious than men and the previously large Blackwhite gap is substantially smaller.

\section{[Table-3]}

Table 3 also includes summary results from mediation analyses, presenting the percentage of each sociodemographic gap that's a function of psychological compensation. These results were calculated in separate models with religiosity as the outcome, the given predictor as the effect-to-be-explained, psychological compensation as the mediator, and all

\footnotetext{
${ }^{11}$ Additional analyses demonstrate the "opiate" function of religion translates into self-reported happiness premiums, especially among the structurally-disadvantaged.

12 The bivariate coefficient for sexuality on religiosity is negative, but positive in the model including covariates.
} 
other measures included as covariates. ${ }^{13}$ First, we see that $113 \%$ of the gender gap in religiosity is a function of psychological compensators (mediation over $100 \%$ indicates the coefficient reversed directions). To put this percentage in context, Miller and Hoffmann's (1995) risk preferences explanation, which continues to elicit debate, accounted for $40 \%$ of this gender gap. $^{14}$

In addition to fully explaining the gender gap in religiosity, psychological compensation also accounts for a significant and substantial percentage of race and ethnicity gaps in religiosity. Although psychological compensation accounts for 59\% of the large Black-white gap, a significant difference persists (perhaps due to the distinctive role of the Black church among African Americans). Psychological compensation reverses the coefficients for ethnicity, class, and sexuality.

Expectation 2 predicted that group differences in religiosity are a function of status and compensation processes. But in an alternative to Expectation 2, one could counter that marginalized groups simply get more comfort from religion because they're more religious. Therefore, I reversed the analyses and considered whether religiosity accounts for group differences in compensation. As shown in Table 3, significant and substantial group differences in psychological compensation persist when accounting for religiosity, suggesting that group

\footnotetext{
${ }^{13}$ The Sobel-Goodman approach takes into account the strength of a relationship before and after the mediator, as well as relationships between the key predictor and mediator, and mediator and outcome. Therefore, mediation/suppression can be significant without a large percentage of mediation/suppression if the predictor is closely related to the mediator and the mediator to the outcome.

${ }^{14}$ Large proportions of gender and others gaps explained by psychological compensators could be due, in part, to compensation-seeking resulting from social processes related to status and power, and does not preclude explanatory power of likely mutually-reinforcing factors such as social expectations, gender performance, and socialized psychological characteristics (Edgell, Frost, and Stewart 2017; Schnabel 2018a).
} 
differences in religiosity do not drive group differences in compensation. ${ }^{15}$ The patterns are consistent with Expectation 2: group differences in religiosity are in part a function of psychological compensation. ${ }^{16}$ This does not mean that greater religiosity cannot lead to greater psychological compensation - in fact, compensation and religiosity are likely bound together in a mutually reinforcing equilibrium — but it does mean that group differences in religiosity are better explained by group differences in psychological compensation than the other way around.

\section{Religion as Schema}

Religion-as-resource plays the compensation-providing opiate function Marx proposed, but does religion suppress group differences in political values? Table 4 explores the model laid out in Figure 1, considering whether psychological compensation (religion-as-resource) suppresses liberal partisanship via religiosity and types of religious beliefs (religion-as-schema). Model 1 shows that disadvantaged groups report more liberal partisanship than advantaged groups. The outcome variable-fielded as a seven-point item ranging from extremely conservative to extremely liberal — is standardized, so that, for example, women are .17 of a standard deviation more liberal than men. Model 2 adds compensation, which is strongly related to partisanship, and the coefficients for the group differences appear larger. For example, when accounting for psychological compensation women are .26 of a standard deviation more liberal than men.

$$
\text { [Table-4] }
$$

Table 4 next shows summary results from mediation tests, which demonstrate the suppression of liberal partisanship is substantial and significant across groups. In other words, group differences in partisanship would be even larger if not for the greater psychological

\footnotetext{
${ }^{15}$ Additional analyses among just the religiously affiliated or including RELTRAD categories demonstrate the patterns aren't due to affiliation or type-of-affiliation differences across advantage/disadvantage-but disadvantaged groups can find certain strains of religion more appealing than others (Hoffmann and Bartkowski 2008).

${ }^{16}$ Compensation also helps explain group differences in literalism and fundamentalism.
} 
compensation disadvantaged groups find in religion and spirituality. For example, the alreadysubstantial Black-white gap in partisanship would be 59\% larger if not for the greater comfort Black Americans find in religion.

Resources and schemas are two key components of structure, and are closely related to one another. We might expect that it's less the religious resources and more the religious schemas that suppress group differences in partisanship. Models 3 and 4 add religiosity and then view of the Bible and type of affiliation to the model. Including these factors does not indicate any further suppression of group differences in partisanship, but, as expected and visualized in Figure 1, they do help explain the pathway by which psychological compensation suppresses group differences in partisanship. Additional path analyses demonstrate that the suppression of group differences in partisanship operates through compensation to religion and from religion to partisanship, with compensation explaining group differences in religiosity and religiosity suppressing group differences in partisanship. Psychological compensation, therefore, is not the key suppressor of partisanship gaps - instead, it is the religiosity, literalism, and fundamentalism facilitated and reinforced by compensation that shape political values.

Psychological compensation measures were only available as part of a 2004 special module, and I have demonstrated that religiosity, literalism, and fundamentalism are the pathway by which compensation promotes conservative politics. ${ }^{17}$ Therefore, I now turn to more recent data (2008-2016) with a larger sample for more political outcomes - and a new measure of sexual orientation (self-identification instead of partnering behavior) — to consider the extent to which religiosity, literalism, and fundamentalism suppress group differences in political views. Table 5 first presents patterns for partisanship, confirming that religion suppresses group

\footnotetext{
${ }^{17}$ Additional analyses found similar patterns for compensation's impact on group differences for other outcomes.
} 
differences in political identity for this larger and more recent sample. Whereas compensation suppresses sexual orientation differences in political values, the other religion measures mediate some of the large difference between LGB and heterosexual views because, despite scoring higher on psychological compensation, sexual minorities are typically less religious, literalist, and fundamentalist.

\section{[Table-5]}

Religiosity, literalism, and fundamentalism are each independently related to political partisanship, but most suppression is already present in the model with just religiosity. This pattern is likely due to larger group differences in religiosity than in literalism and fundamentalism. In fact, higher scores on literalism and fundamentalism among disadvantaged groups are interdependent with group differences in religiosity, which in turn are interdependent with group differences in compensation. Therefore, in confirmation of Expectation 3, it appears highly plausible that compensation makes disadvantaged groups more religious, which promotes traditional religious schemas, which suppress group differences in political values.

The link between religion and politics is so strong in the contemporary U.S. that some liberals select out of affiliation with organized religion. While politics-to-religion selection contributes to the relationship between religiosity and conservative politics for the population as a whole, there is no clear reason to expect disadvantaged groups simply select into religiosity because of their (more liberal) politics. In a related issue, the data used in this study were crosssectional. Additional analyses using GSS panel data presented in the appendix confirm the crosssectional results. ${ }^{18}$ The fact that the patterns hold up in cross-lagged panel models suggests that

\footnotetext{
${ }^{18}$ GLS and cross-lagged models provide similar patterns for the panel data. Moreover, additional checks controlling for losing or gaining a religious affiliation (using a measure of childhood affiliation) for the larger cross-sectional sample demonstrated the suppression patterns aren't simply due to people selecting into or out of being religiously affiliated.
} 
although recent research has emphasized how political views shape religion (e.g., Margolis 2018), religion also shapes political views. And in shaping political views, religion disproportionately conservatives disadvantaged groups due to their greater religiosity, thereby suppressing group differences in political views.

Based on Marx we might expect religion to suppress progressive political views most strongly on economic issues, but I suggested we might alternatively expect stronger suppression on social issues closely tied to religious norms. Table 5 presents results for abortion rights and economic redistribution. In a pattern that seems contradictory to the positionality principle, disadvantaged groups besides sexual minorities tend to be more opposed to abortion rights than their more advantaged counterparts. Perhaps the most surprising pattern is that women are significantly more opposed to a woman's right to choose than are men. But this pattern shifts dramatically when religiosity is added to the model. The coefficient for gender reverses, and is even significant in the opposite direction: if it were not for their greater religiosity, women would actually be significantly more supportive of abortion rights than men. And if not for their greater religiosity than whites, Black Americans would also be substantially more supportive of abortion. Moreover, opposition to abortion among Latinx Americans and those with incomes under $\$ 100 \mathrm{k}$ would be smaller if not for religiosity. And lesser religiosity among sexual minorities helps explain why they're more supportive of abortion. Adding literalism and fundamentalism to the model only enhances these patterns. Therefore, seemingly paradoxical group differences in abortion attitudes are largely a function of religion.

Religion doesn't do much, however, to suppress group differences in support for economic redistribution. The weak patterns for redistricution and strong patterns for abortion lend support to Expectation 4 that religion would more strongly suppress group differences in 
social values than economic values. These patterns are all consistent with the expectation, but it should be further interrogated across a broader range of social and economic issues.

Table 6 presents summary results for additional outcomes. The table focuses on whether progressive politics for each group are suppressed by religiosity (or, alternatively, whether conservative politics are mediated). This suppression is calculated by whether mediation analyses provide evidence for a significant amplification of progressive views among disadvantaged groups when accounting for religiosity. I present patterns for key measures of general partisanship, social attitudes, and economic attitudes.

\section{[Table-6]}

Religiosity significantly suppresses what would otherwise be larger group differences in general politics by gender, race and ethnicity, and class. Demonstrating the political importance of suppression beyond just attitudes, religiosity significantly suppresses the greater likelihood that women, Black and Latinx Americans, and those with less income voted Democratic in presidential elections. Disadvantaged groups are still more likely to vote for Democrats, but they would be even more likely to do so if not for religion. For example, marginal effects based on a model including covariates but not religiosity indicate a 6 percentage point gap between women and men's self-reported voting for Democrats in whatever election was most recent and a 10 point gap when also accounting for religiosity.

Similar patterns appear on attitudes toward specific issues on which some disadvantaged groups are not consistently more progressive. In fact, religiosity significantly suppresses comparatively more progressive views among women, Black and Latinx Americans, and those with lower incomes on all social issues considered, and the percentage of suppression was 
generally large. ${ }^{19}$ Therefore, group differences in sociopolitical attitudes would be more substantial and consistent if not for the greater religiosity of disadvantaged groups reinforced by psychological compensation. This assertion is confirmed by the counterfactual patterns in attitudes by sexual orientation: sexual minorities — who tend to be less rather than more religious than heterosexuals - are more consistently liberal than other disadvantaged groups before accounting for religiosity.

Whereas religiosity is a very consistent suppressor of group differences on general politics and on specific social issues, it is a less consistent suppressor on economic attitudes. Religiosity does significantly suppress group differences on some economic attitudes, but the percentage of suppression is generally low in comparison to the suppression on social attitudes.

I also considered the extent to which the patterns for partisanship and social and economic attitudes are a function of their interrelationship with one another. In results presented in the appendix, I show that the weak suppression of group differences on economic attitudes is explained away when accounting for partisanship. Whereas the weak suppression on economic issues is explained away by partisanship, the strong suppression on social attitudes persists when accounting for partisanship. This pattern is due in part to the weaker correlation between partisanship and social attitudes among marginalized groups than among privileged groups. For example, the correlation between partisanship and abortion attitudes is four times stronger among white (.44) than among Black (.11) Americans. This weaker correlation is highlighted when we consider the coalition of liberals who oppose abortion. The racial composition of liberals who support abortion - here I consider a single binary for support if a woman wants it for any reason-is $73 \%$ white, $13 \%$ Black, $9 \%$ Latinx, and 5\% other race. In stark contrast, the

\footnotetext{
${ }^{19}$ Significance of suppression was not due to the large sample sizes; smaller samples from just one wave at a time generally yield significant suppression across social but not economic issues.
} 
racial composition of liberals who oppose abortion — which is about a third of liberals — are only $48 \%$ white and a full 25\% Black, 22\% Latinx, and 5\% other race. In other words, Black and Latinx Americans are represented at twice the rate among liberals who oppose abortion as among liberals who support abortion, and the greater religiosity of non-white liberals (white liberals are .57 standard deviations below, and Black liberals .34 standard deviations above, average American religiosity) explains this disparity.

In short, suppression on economic attitudes is largely due to the suppression of group differences in general partisanship (i.e., including political identity as a covariate explains away suppression), whereas suppression on social issues generally operates above and beyond general partisanship. In fact, it appears that conservative schemas regarding key social issues like abortion can spill over into conservative partisanship and thereby produce the (less substantial) link between religiosity and conservative economic attitudes.

Although stronger suppression on social issues than on economic issues may appear inconsistent with Marx's argument, it's consistent with this study's argument that religion suppresses progressive politics not because of passive distraction but because of the active conservatizing power of religious schemas. Whereas religiosity is a particularly strong conservatizing force on issues of traditional morality, there is a weaker link between religiosity and economic attitudes. Subsequently, and in support of Expectation 4, religiosity is a potent suppressor of group differences on issues directly tied to religious schemas but not other issues.

\section{CONCLUSION}

One could make the case that Marx and some other classical theorists used a sledgehammer where a scalpel would be better, speaking in broad strokes about religion writ large rather than considering context and complexities or parsing differences between religions. This initial study 
exploring and refining the "opiate" argument likewise cannot fully address the complexities of religion, and focuses on a particular context — the contemporary United States — where Christianity predominates. Drawing on cultural and social psychological theories including structuration, system justification, and compensatory control, I applied the "opiate" argument beyond the economic masses to the socially disenfranchised and to issues beyond economics. I used this extrapolation on classical theory to help explain two contemporary puzzles: why are disadvantaged groups more involved and committed to religious institutions frequently run by more advantaged groups, and why are some structurally-disadvantaged groups not consistently progressive across sociopolitical issues? I found that disadvantaged groups find more psychological compensation in religion, and that religion as an "opiate" of the disenfranchised has two key functions: (1) provides comfort and (2) suppresses progressive political views. Marx's argument was largely context-independent, with non-material belief systems of any kind appealing to and shaping the politics of the economic masses by being palliative and distracting. My argument, however, is more context specific, with the specific nature and context of a religion determining who it disproportionately appeals to (religion as resource) and what values they internalize (religion as schema). Insofar as religion appeals to the disadvantaged, provides comfort, and suppresses progressive politics, it is the opiate of the masses. Religion is not just a distraction, however. Religion is a complex and powerful social structure in which people both receive psychological compensation and develop rules-based belief systems that shape their political values. In other words, religion provides compensation to the structurallydisadvantaged as an alternative source of comfort, validation, and power and shapes their outlook according to specific schemas frequently oriented to traditional social values. Consequently, it may be more accurate to call contemporary American religion the resource-and- 
schema-of-the-people instead of the opium-of-the-people. This extrapolation and refinement of Marx's maxim via structuration theory can be used to rethink religion in the social sciences, explain sociodemographic differences in religiosity, and even account for apparent inconsistencies in the positionality principle.

Sociodemographic differences, and especially gender differences, in religiosity have been contentiously debated for decades. Most research focuses on one sociodemographic gap at a time and thus has not situated individual gaps within a broader and simultaneous consideration of gender, race, ethnicity, class, and sexuality. I found that disadvantaged groups in the domains of gender, race, ethnicity, class, and sexuality all disproportionately receive psychological compensation from religion, which accounts for group religiosity gaps. Only Black vs. white differences persist after accounting for psychological compensation — and this racial gap is less than half of what it was before accounting for compensation. ${ }^{20}$ These findings place gender gaps in religiosity within a larger framework of social status differences and may finally lay to rest essentialist arguments about gender differences in religiosity.

Scholars have long wondered why structurally-disadvantaged groups do not have more consistently progressive attitudes on issues that affect them and other disadvantaged groups. This study explains what at first appear to be inconsistencies in the positionality principle of social attitudes, highlighting how religion complicates the relationship between social status and political views. Marginalized groups are both more liberal and more religious, and religion suppresses what would otherwise be even larger and more consistent group differences in political values. According to Marx, this suppression is due to religion being an "inverted

\footnotetext{
${ }^{20}$ This ongoing racial gap could be the result of the church operating as a semi-involuntary institution in the social life of African-Americans; Black churches have often been one of few institutions that consistently supported and validated African-Americans throughout America's racist history (Davis 1971).
} 
consciousness," or focus on other-worldly distraction to address this-worldly disadvantage. ${ }^{21}$ But at least in the United States, religion and politics are linked in such a way that religion does not make people less political, ${ }^{22}$ it provides schemas that shape their politics according to specific rules and norms (Edgell 2012).

Psychological compensation is an important factor in why some people are more religious than others. If we were to think about religion as a social and psychological good and meaning-making cultural tool, it should not be surprising that people who get more benefit from it would be more religious. Religion is not an impotent cultural resource, however, and provides powerful schemas that can justify and reinforce social boundaries, thereby conservatizing the identity and outlook of those who rely on it in ways that can exacerbate inequalities (Edgell 2012; Pachucki, Pendergrass, and Lamont 2007). Providing a counterfactual for the impact of religious schemas on the political values of structurally-disadvantaged groups, sexual minorities are less religious, literalist, and fundamentalist than heterosexuals. Subsequently, and in confirmation of my argument about religious schemas suppressing what would otherwise be larger and more consistent group differences in politics, sexual minorities are more substantially and consistently liberal than other structurally-disadvantaged groups.

Although religion often promotes traditional values because religious schemas tend to get fixed in a point in time and symbolic boundaries promoted by religion tend to harken back to the past (Edgell 2012), the particular "traditional" issues by which religion (or, more accurately, religions) defines itself shift and are both time- and place-specific (Schnabel 2016a). Marx's

\footnotetext{
${ }^{21}$ In some specific cases, such as Jehovah's Witnesses and Amish, small groups reject earthly politics (and thus do not vote, run for office, etc.) for a reason that matches Marx's religion-as-distraction argument: a belief, based on a biblical statement, about God's kingdom being not of this world.

${ }^{22}$ Rather than promoting political quietude, American religion is politicized. Additional analyses demonstrate religiosity is associated with discussing politics and trying to persuade others more frequently; religion provides a community with whom to discuss politics (and reinforce religious schemas).
} 
religious landscape was distinct from contemporary American religion, which is closely linked to socially conservative politics (Hout and Fischer 2014; Putnam and Campbell 2010). This study indicates that Marx's statement about religion in his historical context can still be applied in principle, but the interrelationship between social status, religious compensation, and political outlook is fluid and specific to a particular inequality-religion-politics nexus. If religious schemas were more closely linked to economically-conservative politics and less closely linked to socially-conservative politics in the contemporary United States, I suspect the patterns demonstrated in this study would have fallen more in line with what Marx might have predicted. And were religions to shift from traditional moralistic schemas to emancipatory schemas, they could become agents for progressive social change instead of bastions of traditional values.

The contemporary United States is a unique context both politically and religiously where religion draws clear symbolic boundaries around issues of gender, sexuality, and other social issues, and where religion and politics are both intertwined and polarized. This situation was not always the case, and while religion in the United States has typically been traditionalist it has not always been so politicized, and in fact conservative Protestants used to be fairly uninvolved in politics (which may have been a time when Marx's argument about religion as not-of-this-world diversion from politics of this world). But when they did become involved in politics, it has been largely for conservative causes and issues, often related to gender and sexuality. Although politics are polarized and we have some level of partisan constraint, this study highlights how factors besides pure partisanship can have implications for specific attitudes. Religion makes it so that some marginalized groups have conservative attitudes despite frequently identifying as liberals and democrats, such as black Americans who are often conservative on certain issues closely tied to religion (e.g., sexuality). 
The patterns in this study were specific to the United States, where Christianity predominates. Although a limitation of this study attempting to lay out and explore broad theoretical and empirical patterns, it points to important directions for future research with opportunities to consider variation within and across contexts. I have begun to explore some of this variation: the supplement to this article notes variation among non-Christians in the United States, and preliminary analyses for a cross-national project suggest that the suppression of gender differences in politics varies by both individual affiliation and country-level religious affiliation. Potential variation across groups and contexts not considered here is certainly not the only limitation pointing to opportunities for future research, and the online supplement covers additional limitations including the (1) complexity of religion and inequality; (2) strangeness and exceptionalism of the U.S. context; (3) existence of varied ways to classify styles and types of religion; (4) potential for the same type of religion to operate differently across time and space; and (5) presence of data limitations and assumptions, such as those for mediation models that are rarely met in any analysis.

Looking beyond the specific case of religion, this study speaks more broadly to the social psychological and cultural theories I considered here and how they help us understand social structures and the people who shape, and are shaped by, them. People do not simply pursue material interests; they also pursue symbolic interests that can and at times do supersede material interests. People can trade — or compensate for lack of access to-capital in one area (such as material standing or social status) for alternative capital in another area (such as symbolic capital or spiritual status), which will shift interests and concerns accordingly. This social psychological negotiation of identity, status, and cultural power by the advantaged and disadvantaged alike occurs within social structures, and such inequalities are thereby structured. Structures interact 
with inequalities and can reinforce them both structurally and ideologically by providing resources, schemas, and ultimately symbolic interests that provide a foundation for a persistent equilibrium of inequality that both seems to counter inequality at the same time that it can make people more likely to accept it. In short, religion and other legitimizing structures contribute to the persistence of unequal power relations by providing benefits that encourage greater internalization of system-justifying belief systems.

This project highlights how we don't need to juxtapose structure vs. culture, but can instead think of structure and culture as operating in tandem and shaping one another-in this case they work together to produce a stable equilibrium of circumstances in which no party has a strong impetus to alter their behavior to change the situation. This insight from the religion case could be applied to the ways additional structures and related belief systems operate in relation to cultural and social psychological processes with implications for inequality. For example, education provides resources that can increase mobility, but it also reinforces status-quojustifying schemas that legitimize the myth of meritocracy. Opening up new directions for potential research, I suspect the reader could think of additional social structures that seemingly ameliorate inequality in ways that provide ideological legitimation for themselves and the status quo more generally. I hope future work will further interrogate the many ways structures can justify and reinforce inequalities among the advantaged and/or disadvantaged via cultural and social psychological processes.

I drew on the classic "opiate" argument to explain otherwise unexpected patterns in inequality and political ideology in the contemporary United States. Extrapolating on and refining the argument for our present times, I made the case that religion can be understood, at least in part, as a social and psychological good. I argued that we can predict how religious 
people will be based on their status in society and subsequent need for and receipt of psychological compensation from religion. Marx was an early proponent of the as-yetunsubstantiated secularization hypothesis, assuming that religion would decline into obscurity as society advanced. Whereas others tended to argue that scientific progress would undermine religion, Marx argued that it was not just science but material security, existential control over one's life, and equality that would lead to religion's demise. Although we have seen religion decline most dramatically in egalitarian Democratic Socialist contexts with strong social safety nets, ${ }^{23}$ neither the egalitarian revolution nor the global demise of religion have occurred. Therefore, we might expect that as long as hardships and inequalities persist, the dual-edged sword that is religion will also persist, providing comfort and strength to the downtrodden at the same time that it promotes schemas that are often more system-justifying than emancipatory.

\footnotetext{
${ }^{23}$ American religion's unique vitality could be in part a function of similarly unique inequalities, policies (e.g., lack of national healthcare that disproportionately affects women, African Americans, etc.), and subsequent vulnerability of structurally-disadvantaged groups.
} 


\section{REFERENCES}

Adamczyk, Amy, Katharine Boyd, and Brittany Hayes. 2016. "Place Matters: Contextualizing the Roles of Religion and Race for Understanding Americans' Attitudes about Homosexuality." Social Science Research 57(1):1-16.

Barkan, Steven. 2014. “Gender and Abortion Attitudes.” Public Opinion Quarterly 78(4):94050 .

Becker, Sascha and Ludger Woessmann. 2013. "Not the Opium of the People." American Economic Review 103(3):539-44.

Bentzen, Jeanet. 2018. "Acts of God? Religiosity and Natural Disasters Across Subnational World Districts.” Economic Journal In Press.

Du Bois, W. E. B. 1903. The Souls of Black Folk. Chicago: A.C. McClurg\&Co.

Bolzendahl, Catherine, Landon Schnabel, and Rottem Sagi. 2019. "Religion and Democratic Citizenship." Politics and Religion 12(4):577-605.

Christopher, Stefan, John Fearon, John Mccoy, and Charles Nobbe. 1971. "Social Deprivation and Religiosity." Journal for the Scientific Study of Religion 10(4):385-92.

Collins, Patricia Hill. 2000. Black Feminist Thought. New York: Routledge.

Davenport, Lauren. 2016. "Beyond Black and White: Biracial Attitudes in Contemporary U.S. Politics." American Political Science Review 110(1):52-67.

Davis, Angela. 1971. Lectures on Liberation. Los Angeles: Committee to Free Angela Davis.

Davis, Kingsley. 1948. Human Society. New York: MacMillan.

Davis, Nancy and Robert Robinson. 1991. “Men's and Women's Consciousness of Gender Inequality." American Sociological Review 56(1):72-84.

Edgell, Penny. 2012. “A Cultural Sociology of Religion.” Annual Review of Sociology 38(1):247-65.

Edgell, Penny. 2017. “An Agenda for Research on American Religion in Light of the 2016 Election." Sociology of Religion 78(1):1-8.

Edgell, Penny and Danielle Docka. 2007. "Beyond the Nuclear Family?” Sociological Forum 22(1):25-50.

Edgell, Penny, Jacqui Frost, and Evan Stewart. 2017. "From Existential to Social Understandings of Risk." Social Currents 4(6):556-74.

Ellison, Christopher and Daisy Fan. 2008. "Daily Spiritual Experiences and Psychological WellBeing among U.S. Adults.” Social Indicators Research 88(2):247-71.

Ellison, Christopher and Darren Sherkat. 1995. “The 'Semi-Involuntary Institution' Revisited.” 
Social Forces 73(4):1415-37.

Ellison, Christopher and Robert Taylor. 1996. "Turning to Prayer." Review of Religious Research 38(2):111-31.

Finke, Roger and Amy Adamczyk. 2008. "Cross-National Moral Beliefs." Sociological Quarterly 49(4):617-52.

Frost, Jacqui and Penny Edgell. 2017. "Distinctiveness Reconsidered." Journal for the Scientific Study of Religion 56(2):277-301.

Gaventa, John. 1982. Power and Powerlessness. Chicago: University of Illinois Press.

Giddens, Anthony. 1984. The Constitution of Society. Berkeley: University of California Press.

Glock, Charles. 1964. "The Role of Deprivation in the Origin and Evolution of Religious Groups." in Religion and Social Conflict, edited by R. Lee and M. Marty. New York: Oxford.

Haidt, Jonathan. 2012. The Righteous Mind. New York: Pantheon.

Higginbotham, Evelyn Brooks. 1993. Righteous Discontent: The Women's Movement in the Black Baptist Church. Cambridge, MA: Harvard University Press.

Hitlin, Steven and Stephen Vaisey. 2013. "The New Sociology of Morality." Annual Review of Sociology 39(1):51-68.

Hoffmann, John and John Bartkowski. 2008. "Gender, Religious Tradition, and Biblical Literalism.” Social Forces 86(3):1245-72.

Hout, Michael and Claude Fischer. 2014. "Explaining Why More Americans Have No Religious Preference: Political Backlash and Generational Succession, 1987-2012." Sociological Science 1(October):423-47.

Hunt, Matthew. 1996. "Individual, Society, or Both? A Comparison of Black, Latino, and White Beliefs about Causes of Poverty." Social Forces 75(1):293-322.

Hunt, Matthew. 2007. "African American, Hispanic, and White Beliefs about Black/White Inequality, 1977-2004.” American Sociological Review 72(3):390-415.

Jost, John, Carlee Beth Hawkins, Brian Nosek, Erin Hennes, Chadly Stern, Samuel Gosling, and Jesse Graham. 2014. "Belief in a Just God (and a Just Society)." Journal of Theoretical and Philosophical Psychology 34(1):56-81.

Jost, John and Orsolya Hunyady. 2002. "The Psychology of System Justification and the Palliative Function of Ideology." European Review of Social Psychology 13(1):111-53.

Jost, John, Melanie Langer, Vivienne Badaan, Flávio Azevedo, Edgardo Etchezahar, Joaquin Ungaretti, and Erin Hennes. 2017. "Ideology and the Limits of Self-Interest." Translational Issues in Psychological Science 3(3):e1-26. 
Kay, Aaron, Danielle Gaucher, Ian McGregor, and Kyle Nash. 2010. "Religious Belief as Compensatory Control." Personality and Social Psychology Review 14(1):37-48.

Kay, Aaron, Jennifer Whitson, Danielle Gaucher, and Adam Galinsky. 2009. "Compensatory Control." Current Directions in Psychological Science 18(5):264-68.

Margolis, Michele. 2018. From Politics to the Pews: How Partisanship and the Political Environment Shape Religious Identity. Chicago: University of Chicago Press.

Marx, Karl. 1970. Marx's Critique of Hegel's Philosophy of Right. Cambridge: Cambridge University Press.

Norris, Pippa and Ronald Inglehart. 2011. Sacred and Secular: Religion and Politics Worldwide. 2nd ed. New York: Cambridge University Press.

Pachucki, Mark, Sabrina Pendergrass, and Michele Lamont. 2007. "Boundary Processes." Poetics 35(6):331-51.

Pargament, Kenneth, Margaret Feuille, and Donna Burdzy. 2011. "Brief RCOPE: Current Psychometric Status of a Short Measure of Religious Coping." Religions 2(4):51-76.

Putnam, Robert and David Campbell. 2010. American Grace: How Religion Divides and Unites Us. New York: Simon \& Schuster.

Schnabel, Landon. 2016a. "Gender and Homosexuality Attitudes across Religious Groups from the 1970s to 2014: Similarity, Distinction, and Adaptation." Social Science Research 55(1):31-47.

Schnabel, Landon. 2016b. "The Gender Pray Gap: Wage Labor and the Religiosity of HighEarning Women and Men." Gender \& Society 30(4):643-69.

Schnabel, Landon. 2018a. "More Religious, Less Dogmatic: Toward a General Framework for Gender Differences in Religion.” Social Science Research 75(1):58-72.

Schnabel, Landon. 2018b. "Sexual Orientation and Social Attitudes.” Socius 4:1-18.

Sewell, William. 1992. “A Theory of Structure.” American Journal of Sociology 98(1):1-29.

Sherkat, Darren. 2016. "Sexuality and Religious Commitment Revisited." Journal for the Scientific Study of Religion 55(4):756-69.

Sherkat, Darren, Kylan DeVries, and Stacia Creek. 2010. "Race, Religion, and Opposition to Same-Sex Marriage.” Social Science Quarterly 91(1):80-98.

Sidanius, Jim, Felicia Pratto, and Lawrence Bobo. 1994. "Social Dominance Orientation and the Political Psychology of Gender." Journal of Personality and Social Psychology 67(6):9981011.

Smith, Tom. 1990. "Classifying Protestant Denominations." Review of Religious Research 31(3):225-45. 
Smith, Tom. 2018. "Response to Measuring Religious Identification in the United States." Journal for the Scientific Study of Religion. 57(4):795-99.

Stark, Rodney and William Bainbridge. 1987. A Theory of Religion. New York: Peter Lang.

Stark, Rodney, Laurence Iannaccone, and Roger Finke. 1996. "Linkages between Economics and Religion.” American Economic Review 86(2):433-37.

Storm, Ingrid. 2017. "Does Economic Insecurity Predict Religiosity?” Sociology of Religion 23(1):11-28.

Swidler, Ann. 1986. “Culture in Action.” American Sociological Review 51(2):273-86.

Vaisey, Stephen. 2009. “Motivation and Justification.” American Journal of Sociology 114(6):1675-1715.

Wedow, Robbee, Landon Schnabel, Lindsey Wedow, and Mary Ellen Konieczny. 2017. “'I'm Gay and I'm Catholic': Negotiating Two Complex Identities at a Catholic University." Sociology of Religion 78(3):289-317.

Wilcox, Clyde. 1992. "Race, Religion, Region and Abortion Attitudes.” Sociology of Religion 53(1):97.

Willer, Robb. 2009. "No Atheists in Foxholes: Motivated Reasoning and Religious Ideology." Pp. 241-64 in Social and Psychological Bases of Ideology and System Justification, edited by J. Jost, A. Kay, and H. Thorisdottir. New York: Oxford University Press.

Wimberley, Dale. 1984. "Socioeconomic Deprivation and Religious Salience." Sociological Quarterly 25(2):223-38.

Young, Olga Antonenko, Robb Willer, and Dacher Keltner. 2013. "“Thou Shalt Not Kill”: Religious Fundamentalism, Conservatism, and Rule-Based Moral Processing." Psychology of Religion and Spirituality 5(2):110-15. 


\section{FIGURES AND TABLES}

Figure 1: Conceptual Diagram of Religion Suppressing Emancipatory Politics

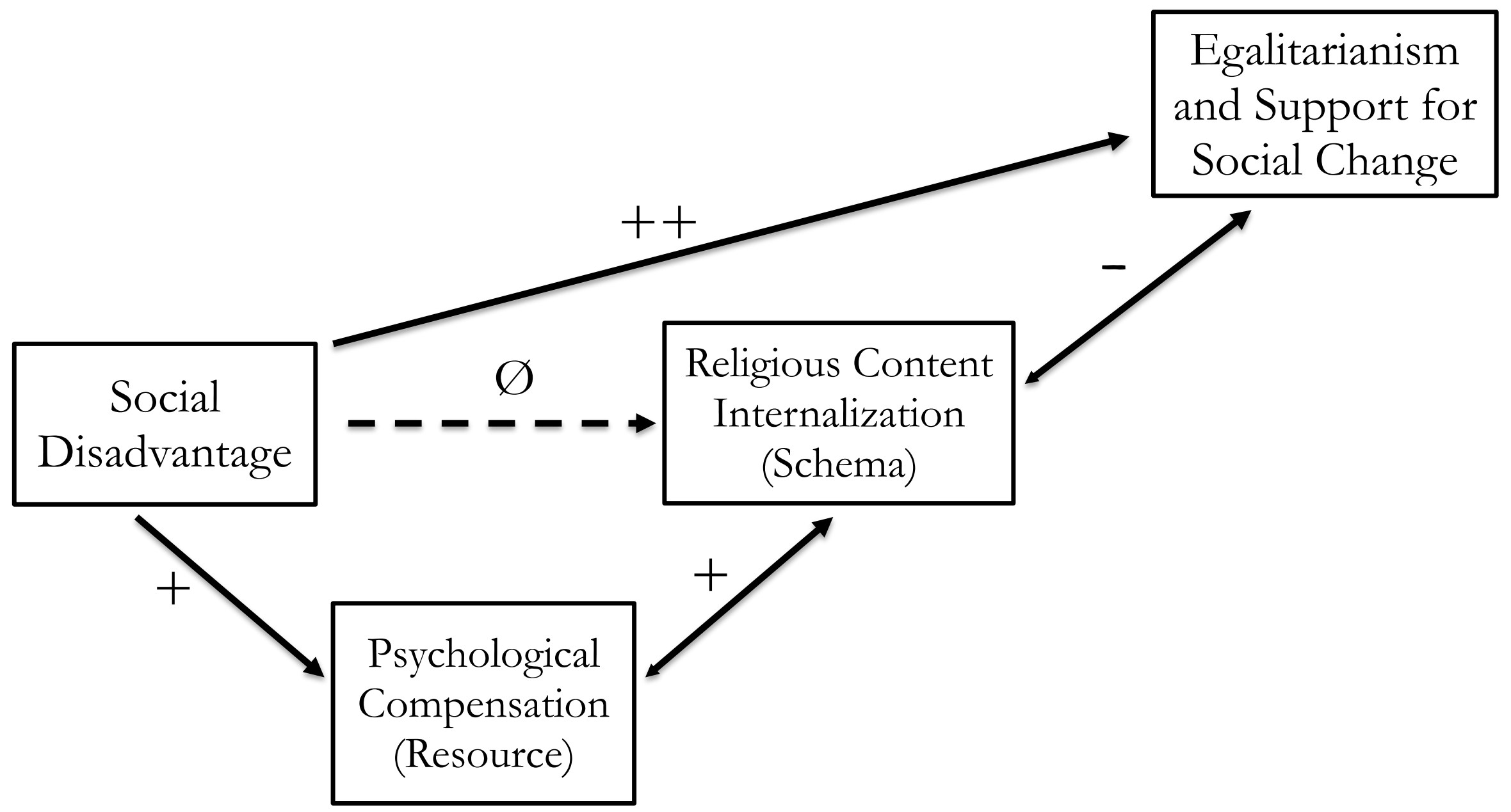


Table 1: Descriptive Statistics

\begin{tabular}{|c|c|c|c|c|c|}
\hline Measures & Metric & $\mathbf{N}$ & $\begin{array}{r}\text { Mean/ } \\
\text { Proportion }\end{array}$ & SD & Range \\
\hline \multicolumn{6}{|l|}{ Social Status Measures } \\
\hline Woman ${ }^{\mathrm{b}}$ & Woman $=1$ & 13,762 & .55 & & \\
\hline Race $^{\mathrm{b}}$ & & 13,762 & & & \\
\hline White, Non-Latinx & White $=1$ & & 67 & & \\
\hline Black, Non-Latinx & Black=1 & & .15 & & \\
\hline Latin $x$ & Latin $x=1$ & & .13 & & \\
\hline Other Race, Non-Latinx & Other Race $=1$ & & .05 & & \\
\hline Income $(10 \% \text { vs. } 90 \%)^{\mathrm{b}}$ & & 13,462 & & & \\
\hline Income over $\$ 100 \mathrm{k}$ & Family Income over $\$ 100 \mathrm{k}$ in 2000 constant dollars & & .10 & & \\
\hline Income under $\$ 100 \mathrm{k}$ & Family Income under $\$ 100 \mathrm{k}$ in 2000 constant dollars & & .80 & & \\
\hline Missing & Category for Missing & & .10 & & \\
\hline Sexuality (Behavior) ${ }^{\mathrm{a}}$ & & 1,323 & & & \\
\hline Heterosexual & Opposite-Sex Partners Only in Last Five Years & & .66 & & \\
\hline LGB & Had a Same-Sex Partner in Last Five Years & & .02 & & \\
\hline No Partnering Information & Category for No Partnering Information (No Partners or Missing) & & .32 & & \\
\hline Sexuality (Self-identification) ${ }^{\mathrm{b}}$ & & 13,762 & & & \\
\hline Heterosexual & Self-Identified Heterosexual & & .75 & & \\
\hline LGB & Self-Identified Lesbian, Gay, or Bisexual & & .04 & & \\
\hline Missing & Category for No Identification Information & & .22 & & \\
\hline \multicolumn{6}{|l|}{ Religion Measures } \\
\hline Psychological Compensation ${ }^{\mathrm{a}}$ & Standardized Seven-Item Scale $(a=.96)$ & 1,323 & .00 & 1.00 & $-1.97-1.46$ \\
\hline Two-item Religiosity Scale ${ }^{a}$ & Standardized Two-Item Scale $(a=.79)$ & 1,323 & .00 & 1.00 & $-1.58-1.69$ \\
\hline Four-item Religiosity Scale ${ }^{b}$ & Standardized Four-Item Scale $(a=.85)$ & 13,762 & .00 & 1.00 & $-1.87-1.87$ \\
\hline View of Bible & & 13,762 & & & \\
\hline Book of Fables & View Bible as a Book of Fables & & .21 & & \\
\hline Inspired, Not Literal & View Bible as Inspired, but Not Literal & & .44 & & \\
\hline Literal Word of God & View Bible as Literal Word of God & & .32 & & \\
\hline Other Volunteered & Category for Other Volunteered Responses & & .01 & & \\
\hline Missing & Category for Missing & & .02 & & \\
\hline Type of Affiliation ${ }^{\mathrm{b}}$ & & 13,762 & & & \\
\hline Liberal & Affiliation Classified as Liberal (Includes No Affiliation) & & .32 & & \\
\hline Moderate & Affiliation Classified as Moderate & & .39 & & \\
\hline Fundamentalist & Affiliation Classified as Fundamentalist & & .25 & & \\
\hline Other/Missing & Category for Other or Missing & & .05 & & \\
\hline \multicolumn{6}{|l|}{ Key Political Outcomes } \\
\hline Political Partisanship ${ }^{b}$ & Extremely Conservative $=1$ to Extremely Liberal $=7$, Standardized & 13,218 & .00 & 1.00 & $-2.00-2.10$ \\
\hline Abortion Rights Scale ${ }^{b}$ & Standardized 7-item Support for Abortion Rights Scale $(a=.89)$ & 9,020 & .00 & 1.00 & $-2.34-1.42$ \\
\hline Redistribution ${ }^{\mathrm{b}}$ & $\begin{array}{l}\text { No Government Action=1 to Government Should Reduce } \\
\text { Economic Inequality=7, Standardized }\end{array}$ & 9,159 & .00 & 1.00 & $-1.66-1.31$ \\
\hline
\end{tabular}

${ }^{\mathrm{a}}$ Cases from 2004; ${ }^{\mathrm{b}}$ Cases from 2008-2018 
Table 2: Disadvantaged Social Status Predicting Standardized Psychological Compensation, Religiosity, View of Bible, and Affiliation Type

\begin{tabular}{lcccc}
\hline & $\begin{array}{c}\text { Psychological } \\
\text { Compensation }\end{array}$ & Religiosity & View of Bible & $\begin{array}{c}\text { Affiliation } \\
\text { Type }\end{array}$ \\
\hline Woman & $.44^{* * *}$ & $.24^{* * *}$ & $.19^{* * *}$ & $.11^{* * * *}$ \\
& $(.05)$ & $(.01)$ & $(.01)$ & $(.01)$ \\
Black & $.60^{* * *}$ & $.44^{* * *}$ & $.49^{* * *}$ & $.53^{* * *}$ \\
& $(.08)$ & $(.02)$ & $(.02)$ & $(.02)$ \\
Latinx & $.40^{* * *}$ & $.19^{* * *}$ & $.20^{* * *}$ & $.08^{* *}$ \\
& $(.09)$ & $(.02)$ & $(.02)$ & $(.02)$ \\
Income under $\$ 100 \mathrm{k})$ & $.28^{* *}$ & $.09^{* * *}$ & $.19^{* * *}$ & $.16^{* * *}$ \\
& $(.09)$ & $(.02)$ & $(.02)$ & $(.02)$ \\
LGB & $.41^{*}$ & $-.15^{* * *}$ & $-.21^{* * *}$ & $-.18^{* * *}$ \\
& $(.17)$ & $(.04)$ & $(.04)$ & $(.04)$ \\
Covariates & Yes & Yes & Yes & Yes \\
Constant & -1.13 & -1.09 & -0.61 & -0.49 \\
\hline$N$ & 1,323 & 21,052 & 17,521 & 20,127 \\
\hline
\end{tabular}

Standard errors in parentheses

Source: General Social Survey 2004-2018

Note: Models also include an "other race" category, an income category for missing, and a sexuality category for no partnering information, as well as the following covariates: age, education, marital status, parental status, region, rurality, and, when an outcome measure was fielded in multiple years, a series of binary controls for survey year. These models use all available cases for each outcome from 2004 to 2018 . Other analyses focus on either 2004 or 2008-2018.

${ }^{*} p<0.05,{ }^{* * *} p<0.01,{ }^{* * * *} p<0.001$ (two-tailed) 
Table 3: Disadvantaged Social Status and Psychological Compensation Predicting Standardized Religiosity

\begin{tabular}{|c|c|c|c|c|}
\hline & \multicolumn{3}{|c|}{ Religiosity } & $\begin{array}{l}\text { Psychological } \\
\text { Compensation }\end{array}$ \\
\hline & $\begin{array}{c}\text { Without } \\
\text { Psychological } \\
\text { Compensation }\end{array}$ & $\begin{array}{c}\text { Accounting } \\
\text { for } \\
\text { Psychological } \\
\text { Compensation }\end{array}$ & $\begin{array}{c}\text { \% of Religiosity } \\
\text { Difference } \\
\text { Mediated by } \\
\text { Psychological } \\
\text { Compensation } \\
\end{array}$ & $\begin{array}{l}\text { Accounting } \\
\text { for Religiosity }\end{array}$ \\
\hline Woman & $\begin{array}{l}.23^{* * *} \\
(.05)\end{array}$ & $\begin{array}{l}-.03 \\
(.04)\end{array}$ & $113 \%^{* * *}$ & $\begin{array}{l}.31^{* * *} \\
(.04)\end{array}$ \\
\hline Black & $\begin{array}{l}.61^{* * *} \\
(.09)\end{array}$ & $\begin{array}{l}.25^{* * *} \\
(.07)\end{array}$ & $59 \%^{* * *}$ & $\begin{array}{l}.25^{* * *} \\
(.07)\end{array}$ \\
\hline Latinx & $\begin{array}{l}.16 \\
(.10)\end{array}$ & $\begin{array}{l}-.08 \\
(.08)\end{array}$ & $148 \%$ *** & $\begin{array}{l}.31^{* * *} \\
(.08)\end{array}$ \\
\hline Income under $\$ 100 \mathrm{k}$ & $\begin{array}{l}.16 \\
(.09)\end{array}$ & $\begin{array}{l}-.01 \\
(.07)\end{array}$ & $109 \%^{* *}$ & $\begin{array}{l}.19^{* * *} \\
(.07)\end{array}$ \\
\hline LGB & $\begin{array}{l}.01 \\
(.18)\end{array}$ & $\begin{array}{l}-.23 \\
(.15)\end{array}$ & $1854 \% *$ & $\begin{array}{l}.40^{* *} \\
(.14)\end{array}$ \\
\hline Psychological Compensation & & $\begin{array}{l}.60^{* * *} \\
(.02)\end{array}$ & & - \\
\hline Religiosity & - & - & & $\begin{array}{l}.57^{* * *} \\
(0.02)\end{array}$ \\
\hline Covariates & Yes & Yes & & Yes \\
\hline Constant & -1.12 & -.43 & & -.50 \\
\hline$N$ & 1,323 & 1,323 & & 1,323 \\
\hline
\end{tabular}

Standard errors in parentheses

Source: 2004 General Social Survey

Note: Models also include an "other race" category, an income category for missing, and a sexuality category for no partnering information, as well as the following covariates: age, education, marital status, parental status, region, and rurality. The identical coefficients and standard errors for Black in Models 2 and 3 is not an error, the values just happen to be the same out to two decimal places. Sobel-Goodman tests used to determine percentage and significance of religiosity mediated by psychological compensation.

${ }^{*} p<0.05,{ }^{* *} p<0.01,{ }^{* * *} p<0.001$ (two-tailed) 
Table 4: Disadvantaged Social Status and Psychological Compensation Predicting Standardized Liberal Partisanship

\begin{tabular}{|c|c|c|c|c|c|}
\hline & $\begin{array}{c}\text { Model 1: } \\
\text { Without } \\
\text { Compensation } \\
\end{array}$ & $\begin{array}{c}\text { Model 2: } \\
\text { With } \\
\text { Compensation } \\
\end{array}$ & $\begin{array}{c}\% \text { of Total } \\
\text { Difference Mediated } \\
\text { by Compensation }^{\mathrm{a}}\end{array}$ & $\begin{array}{l}\text { Model 3: } \\
\text { With } \\
\text { Religiosity }\end{array}$ & $\begin{array}{l}\text { Model 4: } \\
\text { Full Model }\end{array}$ \\
\hline Woman & $\begin{array}{l}.17^{* *} \\
(.06)\end{array}$ & $\begin{array}{l}.26^{* * *} \\
(.06)\end{array}$ & $-53 \%^{* * *}$ & $\begin{array}{l}.26^{* * *} \\
(.06)\end{array}$ & $\begin{array}{l}.24^{* * *} \\
(.06)\end{array}$ \\
\hline Black & $\begin{array}{l}.21^{*} \\
(.09)\end{array}$ & $\begin{array}{l}.33^{* * *} \\
(.09)\end{array}$ & $-59 \%{ }^{* * *}$ & $\begin{array}{l}.37^{* * *} \\
(.09)\end{array}$ & $\begin{array}{l}.35^{* * *} \\
(.09)\end{array}$ \\
\hline Latinx & $\begin{array}{l}.12 \\
(.10)\end{array}$ & $\begin{array}{l}.19 \\
(.10)\end{array}$ & $-61 \%{ }^{* * *}$ & $\begin{array}{l}.18 \\
(.10)\end{array}$ & $\begin{array}{l}.20^{*} \\
(.10)\end{array}$ \\
\hline Income under $\$ 100 \mathrm{k}$ & $\begin{array}{l}.10 \\
(.09)\end{array}$ & $\begin{array}{l}.15 \\
(.09)\end{array}$ & $-31 \%{ }^{* *}$ & $\begin{array}{l}.15 \\
(.09)\end{array}$ & $\begin{array}{l}.17 \\
(.09)\end{array}$ \\
\hline LGB & $\begin{array}{l}.47^{*} \\
(.18)\end{array}$ & $\begin{array}{l}.56^{* *} \\
(.18)\end{array}$ & $-18 \%{ }^{*}$ & $\begin{array}{l}.52^{* *} \\
(.18)\end{array}$ & $\begin{array}{l}.45^{*} \\
(.18)\end{array}$ \\
\hline Psychological Compensation & & $\begin{array}{l}-.20^{* * * *} \\
(.03)\end{array}$ & & $\begin{array}{l}-.10^{* *} \\
(.04)\end{array}$ & $\begin{array}{l}-.05 \\
(04)\end{array}$ \\
\hline Religiosity & & & & $\begin{array}{l}-.16^{* * * *} \\
(.03)\end{array}$ & $\begin{array}{l}-.10^{* * *} \\
(.04)\end{array}$ \\
\hline Bible Inspired & & & & & $\begin{array}{l}-.35^{* * * *} \\
(.08)\end{array}$ \\
\hline Bible Literal & & & & & $\begin{array}{l}-.43^{* * * *} \\
(.10)\end{array}$ \\
\hline Moderate Affiliation & & & & & $\begin{array}{l}-.16^{*} \\
(.07)\end{array}$ \\
\hline Fundamentalist Affiliation & & & & & $\begin{array}{l}-.08 \\
(.08)\end{array}$ \\
\hline Covariates & Yes & Yes & & Yes & Yes \\
\hline Constant & .36 & .13 & & .06 & .51 \\
\hline$N$ & 1,294 & 1,294 & & 1,294 & 1,294 \\
\hline
\end{tabular}

Standard errors in parentheses

Source: 2004 General Social Survey

Note: Models also include an "other race" category, an income category for missing, a sexuality category for no partnering information, Bible categories for other and missing, and a fundamentalism category for other/missing, as well as the following covariates: age, education, marital status, parental status, region, and rurality. Sobel-Goodman tests used to determine percentage and significance of partisanship mediated by psychological compensation.

${ }^{a}$ Negative mediation is suppression (i.e., psychological compensation suppresses group differences in partisanship). Mediation can be significant without the original effect being significant when the relationships between the predictor and mediator and between the mediator and outcome are strong.

${ }^{*} p<0.05,{ }^{* *} p<0.01,{ }^{* * *} p<0.001$ (two-tailed) 
Table 5: Religion as a Suppressor of Group Differences in Standardized Liberal Partisanship, Support for Abortion Rights, and Support for Redistribution

\begin{tabular}{|c|c|c|c|c|c|c|c|c|c|}
\hline & \multicolumn{3}{|c|}{ Liberal Partisanship } & \multicolumn{3}{|c|}{ Abortion Rights Scale $(a=\mathbf{8 9})$} & \multicolumn{3}{|c|}{ Redistribution } \\
\hline & Model 1 & Model 2 & Model 3 & Model 1 & Model 2 & Model 3 & Model 1 & Model 2 & Model 3 \\
\hline \multirow[t]{2}{*}{ Woman } & $.08^{* * *}$ & $.17^{* * *}$ & $.17^{* * *}$ & $-.08^{* * *}$ & $.05^{* *}$ & $.06^{* *}$ & $.15^{* * *}$ & $.19^{* * *}$ & $.19^{* * *}$ \\
\hline & $(.02)$ & $(.02)$ & $(.02)$ & $(.02)$ & $(.02)$ & $(.02)$ & $(.02)$ & $(.02)$ & $(.02)$ \\
\hline \multirow[t]{2}{*}{ Black } & $.24^{* * *}$ & $.38^{* * *}$ & $.42^{* * *}$ & -.03 & $.20^{* * *}$ & $.25^{* * *}$ & $.42^{* * *}$ & $.47^{* * *}$ & $.47^{* * *}$ \\
\hline & $(.03)$ & $(.02)$ & $(.03)$ & $(.03)$ & $(.03)$ & $(.03)$ & $(.03)$ & $(.03)$ & $(.03)$ \\
\hline \multirow[t]{2}{*}{ Latin $x$} & $.10^{* * *}$ & $.18^{* * *}$ & $.19^{* * *}$ & $-.27^{* * *}$ & $-.15^{* * *}$ & $-.12^{* * *}$ & $.22^{* * *}$ & $.24^{* * *}$ & $.25^{* * *}$ \\
\hline & $(.03)$ & $(.03)$ & $(.03)$ & $(.03)$ & $(.03)$ & $(.03)$ & $(.03)$ & $(.03)$ & $(.03)$ \\
\hline \multirow[t]{2}{*}{ Income under $\$ 100 \mathrm{k}$} & .03 & $.08^{* * *}$ & $.10^{* * *}$ & $-.22^{* * *}$ & $-.17^{* * *}$ & $-.14^{* * *}$ & $.25^{* * *}$ & $.27^{* * *}$ & $.27^{* * *}$ \\
\hline & $(.03)$ & $(.03)$ & $(.03)$ & $(.04)$ & $(.03)$ & $(.03)$ & $(.04)$ & $(.04)$ & $(.04)$ \\
\hline \multirow[t]{2}{*}{ LGB } & $.46^{* * *}$ & $.39^{* * *}$ & $.35^{* * *}$ & $.24^{* * *}$ & $.16^{* *}$ & $.11^{* * *}$ & $.17^{* * *}$ & $.14^{* *}$ & $.12^{*}$ \\
\hline & $(.05)$ & $(.04)$ & $(.04)$ & $(.06)$ & $(.05)$ & $(.05)$ & $(.05)$ & $(.05)$ & $(.05)$ \\
\hline \multirow[t]{2}{*}{ Religiosity } & & $-.30^{* * *}$ & $-.19^{* * *}$ & & $-.41^{* * *}$ & $-.30^{* * *}$ & & $-.11^{* * *}$ & $-.07^{* * *}$ \\
\hline & & $(.01)$ & $(.01)$ & & $(.01)$ & $(.01)$ & & $(.01)$ & $(.01)$ \\
\hline \multirow[t]{2}{*}{ Bible Inspired } & & & $-.26^{* * *}$ & & & $-.13^{* * *}$ & & & $-.13^{* * *}$ \\
\hline & & & $(.02)$ & & & $(.03)$ & & & $(.03)$ \\
\hline \multirow[t]{2}{*}{ Bible Literal } & & & $-.40^{* * * *}$ & & & $-.53^{* * * *}$ & & & $-.09^{*}$ \\
\hline & & & $(.03)$ & & & $(.03)$ & & & $(.04)$ \\
\hline \multirow[t]{2}{*}{ Moderate Affiliation } & & & $-.09^{* * * *}$ & & & $-.07^{* *}$ & & & $-.08^{* *}$ \\
\hline & & & $(.02)$ & & & $(.03)$ & & & $(.03)$ \\
\hline \multirow[t]{2}{*}{ Fundamentalist Affiliation } & & & $-.16^{* * *}$ & & & $-.09^{* * *}$ & & & $-.08^{*}$ \\
\hline & & & $(.03)$ & & & $(.03)$ & & & $(.03)$ \\
\hline Covariates & Yes & Yes & Yes & Yes & Yes & Yes & Yes & Yes & Yes \\
\hline Constant & .30 & -.10 & .23 & .30 & -.26 & .02 & .13 & -.01 & .13 \\
\hline$N$ & 13,218 & 13,218 & 13,218 & 9,020 & 9,020 & 9,020 & 9,159 & 9,159 & 9,159 \\
\hline
\end{tabular}

Standard errors in parentheses

Source: 2008-2018 General Social Survey

Note: Models also include an "other race" category, an income category for missing, and a sexuality category for no orientation information, as well as the

following covariates: age, education, marital status, parental status, region, rurality, and a series of binary variables for survey year. Models with view of the Bible and affiliation also include categories (not shown) for other volunteered responses or missing information.

${ }^{*} p<0.05,{ }^{* *} p<0.01,{ }^{* * *} p<0.001$ (two-tailed) 


\begin{tabular}{|c|c|c|c|c|c|c|}
\hline \multirow[b]{2}{*}{ Political Measures } & \multicolumn{6}{|c|}{ Group Differences Suppressed by Religiosity } \\
\hline & $\mathbf{N}$ & Woman & Black & Latinx & $\begin{array}{l}\text { Under } \\
\$ 100 \mathrm{k}\end{array}$ & LGB \\
\hline \multicolumn{7}{|l|}{ General Politics } \\
\hline Liberal Partisanship & 13,218 & $*$ & $*$ & * & $*$ & \\
\hline Party Identification (Strong GOP $=1$ to Strong $D e m=7^{a}$ ) & 13,646 & $*$ & $*$ & $*$ & $*$ & \\
\hline Voted for Democrat in Previous Election (if voted) & $8,522^{\mathrm{b}}$ & $*$ & $*$ & $*$ & $*$ & \\
\hline \multicolumn{7}{|c|}{ Social Attitudes That Sometimes Appear to Contradict the Positionality Principle } \\
\hline Abortion Attitudes Scale (7 items; $a=.89$ ) & 9,020 & $*$ & $*$ & $*$ & $*$ & \\
\hline Same-Sex Relationship Morality & 8,668 & $*$ & $*$ & $*$ & $*$ & \\
\hline Other Sex-Related Attitudes Scale (5 items; $a=.62$ ) & 13,682 & $*$ & $*$ & $*$ & $*$ & \\
\hline Same-Sex Marriage & 8,975 & $*$ & $*$ & $*$ & $*$ & \\
\hline Gender Attitudes Scale (4 items; $a=.66$ ) & 9,159 & $*$ & $*$ & $*$ & $*$ & \\
\hline Legislation of Morality Scale (4 items; $a=.40^{\mathrm{c}}$ ) & 4,044 & $*$ & $*$ & $*$ & $*$ & \\
\hline Free Speech Scale ( 18 items; $a=.91)$ & 9,090 & $*$ & $*$ & $*$ & $*$ & \\
\hline Required Prayer in Public Schools & 8,762 & $*$ & $*$ & $*$ & $*$ & \\
\hline Physician Assisted Suicide & 8,200 & $*$ & $*$ & $*$ & $*$ & \\
\hline Corporal Punishment & 9,040 & $*$ & $*$ & $*$ & * & \\
\hline Science and Environment Scale ( 15 items; $a=.80$ ) & 4,429 & $*$ & $*$ & $*$ & $*$ & \\
\hline Marijuana Legalization & 8,590 & $*$ & $*$ & $*$ & $*$ & \\
\hline \multicolumn{7}{|l|}{ Economic Attitudes } \\
\hline Governmental Redistribution & 9,159 & $*$ & $*$ & $*$ & $*$ & \\
\hline More Welfare Spending & 6,624 & $*$ & $*$ & $*$ & $*$ & \\
\hline Workers Need Strong Unions & 3,604 & & & & & \\
\hline Confidence in Organized Labor & 8,817 & $*$ & $*$ & $*$ & $*$ & \\
\hline The Rich Should Be Taxed More & 2,330 & $*$ & $*$ & $*$ & & \\
\hline Right to Adequate Standard of Living & 1,231 & & & & & \\
\hline Large Income Inequality Not Necessary for Prosperity & 1,004 & & & & & \\
\hline Inequality Persists Because It Benefits the Rich & 997 & & & & & \\
\hline
\end{tabular}

Source: 2008-2018 General Social Survey

${ }^{a}$ A categorical measure yields equivalent results.

${ }^{\mathrm{b}}$ Analysis limited to those who self-reported that they had voted.

${ }^{\mathrm{c}}$ Although the alpha for this scale is low, I present it because this was a GSS-formulated scale and the patterns are the same for the individual measures.

Note: Models include gender, race, class (family earnings), sexuality, age, education, marital status, parental status, region, rurality, and survey year.

* indicates suppression of liberal response or mediation of conservative response by psychological compensators $(p<$ .05 in Sobel-Goodman tests using sgmediation in Stata) 